\section{Effects of Job Involvement, Managerial Attitudes, and Information Sharing on Controllers Performance in the Budgetary Context}

\author{
Micheli Aparecida Lunardi ${ }^{1}$ \\ Vinícius Costa da Silva Zonatto ${ }^{1}$ \\ Juliana Constâncio Nascimento ${ }^{1}$ \\ ${ }^{1}$ Universidade Regional de Blumenau, Programa de Pós-Graduação \\ em Ciências Contábeis, Blumenau, Brasil.
}

Received on

04/12/2018

Approved on

$12 / 15 / 2018$

Responsible editor:

Prof. Dr. Ivam Ricardo Peleias

Evaluation process:

Double Blind Review

\begin{abstract}
Purpose - This study investigates the intervening effects of job involvement, managerial attitudes, and information sharing in the relationship between the budget participation and managerial performance of controllers of companies operating in Brazil.
\end{abstract}

Design/methodology/approach - Descriptive research was performed through a survey with 318 respondents with budgetary responsibility in companies operating in Brazil. The individuals participating in the study carry out the role of controller, controller manager, or controller coordinator. The theoretical relations investigated in this research were tested using the structural equation modeling technique.

Findings - The results showed that budget participation positively influences job involvement, which showed a direct and indirect influence on managerial performance, mediated by managerial attitudes. Job involvement influences controllers' managerial attitudes and their willingness to share information with superiors. However, vertical information sharing does not have a direct influence on managerial performance.

Originality/value - The aim is to contribute to the existing knowledge related to this subject, by providing evidence of the effects of controllers' budgetary participation on their job involvement. The expectation is to produce evidence of the direct and indirect effects of involvement in the relationship between budget participation and managerial performance, mediated by managerial attitudes towards the budget and the willingness to share information with superiors.

Keywords - Budget Participation, Job Involvement; Management attitude; Vertical Information Sharing; Management Performance

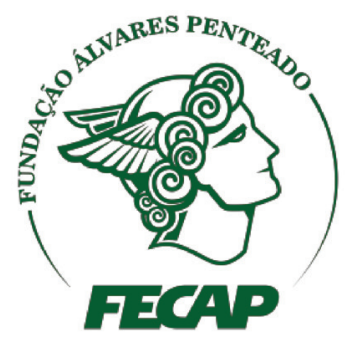

Review of Business Management 


\section{Introduction}

Budget participation refers to the extent to which managers participate in budget preparation and influence budget objectives in their areas of responsibility (Kenis, 1979). Behavioral studies on budget participation gained momentum in the work of Argyris (1952), who provided qualitative evidence that the budget can negatively affect the mental state and behavior of employees.

According to Katz and Kahn (1978) and Diefendorff, Brown, Kamin, and Lord (2002), the effective functioning of an organization requires employees not only to perform their prescribed roles but also involves behaviors that go beyond formal obligations. An organization's budget processes can lead to an increase in a subordinate's involvement with the organization, which can then result in higher performance in the subordinate's tasks (Macinati and Rizzo, 2016; Shields and Shields, 1998).

The subordinate's involvement in the budget process has important cognitive effects that can promote the emergence of feelings of ownership and clarity in the performance of his/ her functions. Engagement at work increases motivational processes that in turn influence job performance as well as other relevant outcomes in this context (Diefendorff et al., 2002), such as managerial attitudes and the propensity of individuals to share private information with their superiors. It is believed that greater manager involvement in work can positively influence these relationships.

For Moynihan and Pandey (2007), job involvement can be highlighted as an important attitude of employees. However, budgets improperly applied can lead to dysfunctional behaviors and negative attitudes among organizational members (Argyris, 1952). Most of the studies developed on this topic have focused on whether high budget participation leads to better performance and attitudes at work (Govindarajan, 1989).

With regard to attitudes, Milani (1975) found that participation was positively and significantly associated with the managerial attitudes of the subordinates, which suggests that under conditions of greater budgetary participation, it becomes possible to improve the involvement of managers in the work. However, the evidence for the relationship between budget participation and managerial performance has presented conflicting and inconclusive results among some studies (Dani, Zonatto, and Diehl, 2017; Derfuss, 2016), suggesting that there are other intervening variables that determine the effects of participation on performance.

In this context, one research gap identified in the literature involves the intervening effects of workforce involvement in the relationship between budget participation and managerial performance. It is understood that participation alone is not able to ensure that subordinate managers will perform better, which is when they make more effort when carrying out their tasks, engaging with their work activities to ensure that established objectives can be achieved.

Thus, it is possible that, under conditions of greater budgetary participation, a higher level of managerial involvement in work occurs, which can result in managers' proactive management attitudes towards the budget, as well as positively influencing their propensity to share information with their superiors, which can result in better managerial performance. However, such relationships have not been investigated in the accounting behavioral literature, the motivation for which this study was developed.

In view of the above, the research question that guides this research is: What are the intervening effects of job involvement, managerial attitudes, and information sharing in the relationship between the budget participation and managerial performance of controllers? The main objective of this research is to investigate the intervening effects of job involvement, managerial attitudes, and information sharing in the relationship between the budget participation and managerial performance of controllers of companies operating in Brazil. 
In this investigation, the research subject is the manager responsible for the Controllership unit, which constitutes an organizational unit subordinate to a superior management division in the organization, with budgetary management responsibilities. Therefore, his/her hierarchical level in the organization is mid-level. Controlling is an important area of management support in organizations, providing a source of information. Thus, the controller is one of the managers who enable the attainment of organizational objectives (Sathe, 1983). Zonatto (2014) and Palomino and Frezatti (2016) highlight the paucity of studies developed specifically using a sample of controllers, which constitutes an opportunity for new studies.

Managers' perception that an organization's success may be partially linked to employee involvement in organizational processes, such as the budget, has led to a continuing interest of managers and researchers in analyzing employee involvement in relation to managerial performance (Vandenberg, Richardson, and Eastman, 1999). Worker involvement in the budget can contribute to greater clarity of the role of individuals in organizational activities since involvement can provide information that allows them to understand the expectations associated with their role, tasks, and responsibilities (Macinati and Rizzo, 2016).

Although budgets are often criticized by researchers and tool users, they are still widely used in most organizations (Libby and Lindsay, 2010). However, the budget tends to be less criticized when the subordinate's level of involvement and worker involvement during the budget process is high (Sponem and Lambert, 2010). Budgetary participation has been studied more frequently in international literature (Lavarda and Fank, 2014). In Brazil, behavioral research associated with budget participation and managerial performance is scarce, which makes the application of this study relevant (Dani et al., 2017; Santos et al., 2014).

Likewise, other studies developed under the configuration proposed in this research were not identified in the literature reviewed. Therefore, it is hoped that this study will contribute to the existing knowledge related to this subject, providing evidence of the effects of the budget participation of controllers of companies that operate in Brazil on their job involvement. Also, it is expected to produce evidence of the direct and indirect effects of this involvement in the relationship between budget participation and managerial performance, mediated by the managerial attitudes of these professionals in relation to the budget and their willingness to share information with their superiors.

\section{Theoretical basis and research hypotheses}

\section{I Budget Participation, Work Involvement, and Management Performance}

In most organizations, budgeting plays a crucial role in planning and control, resource allocation, and coordination (Hannan, Rankin, and Towry, 2010). The business budget as a control tool has become an important instrument for organizations, due to, among other reasons, the need to maintain a balance between financial forecasts and the results actually achieved by department managers (Santos et al., 2014).

For Milani (1975) and Bruns and Waterhouse (1975), budgeting is one of the many administrative activities that evidence certain types of human reactions. Nouri and Parker (1998) argued that when subordinates become involved in budgeting, they become familiar with budget objectives. Consequently, there is an increase in their association not only with the budget objectives but also with all the organizational objectives.

Budgetary participation allows subordinates to better understand the budgeting process (Dani, Zonatto, and Diehl, 2017; Derfuss, 2016; Nouri and Parker, 1998). Shields and Shields (1998) suggested that the budget participation process increases subordinate 
confidence, control, and subordinate involvement with the organization (Chong, Eggleton, and Leong, 2006).

Job involvement relates to the cognitive belief that the work meets the needs of the worker. It represents the degree to which an individual identifies with his or her work, both at work and outside it (Brown, 1996). Christian, Garza, and Slaughter (2011) explain that job involvement relates to how much work can meet the needs of an individual. It is the level of identification of the individual with the work performed (Cavalcante, Siqueira, and Kuniyoshi, 2014; Siqueira, 2008).

Thus, based on the above, the first hypothesis investigated seeks to analyze the direct relationship between the budget participation of controllers of companies operating in Brazil and their involvement in the work: $H_{1}$ : Budgetary participation is positively related to job involvement.

The importance of developing human resources policies and practices, high-performance work systems, and high job involvement has been demonstrated in the literature on strategic human resources management (Oliveira and Rocha, 2017). However, empirical research on engagement at work does not seem to support claims of the influence of worker involvement in the budget process on managerial performance.

The evidence produced by Brown and Leigh (1996) indicates a possible correlation between engagement at work and the managerial performance of subordinates. Bakker, Schaufeli, Leiter, and Taris (2008) point out that one of the reasons why workers develop better managerial performance in an organization is due to the creation of job involvement.

Other researchers have been interested in the relationship between job involvement and organizational variables (Kanungo, 1982). Although engagement at work is considered a key factor that influences important individual and organizational outcomes (Lawler, 1986), the study by Brown (1996) showed a non-significant relationship between subordinate engagement at work and managerial performance.
Thus, for this research, it is understood that under conditions of higher levels of budgetary participation, it becomes possible to increase the involvement of controllers in the work, which would positively impact their performance. Therefore, the second hypothesis to be tested in the research establishes that: $H_{2}$ : Job involvement is positively associated with managerial performance.

\subsection{Job Involvement, Management Attitudes, and Management Performance}

Although budgetary participation in some studies has shown positive and direct effects on managerial attitudes and performance, in most studies the effects of budget participation depend on another intervening variable (Shields and Shields, 2008). Models based on psychological theories suggest that participation is related to performance through the identification and involvement of the subordinate with the budget objectives (Murray, 1990), which may lead to a better managerial attitude.

Milani (1975) defined attitude in terms of employees' feelings and predispositions towards their jobs and employers in a budget context. For Yukl (1971), the results of many studies have supported the positive effects of budget participation on the attitudes of subordinates. In most cases, attitudes towards work have been shown to be an intervening factor that affects managerial performance when subordinates participate in budget activities (Yuen, 2007).

Thus, one reason to examine this variable in this study is the belief that a managerial attitude appropriate to the company will lead to more effective managerial performance, driven by the conditions in which this participation occurs and the level of involvement.

Budget participation can be most effective when staff members have a positive attitude that will ultimately improve employee performance (Yuen, 2007). Attitude at work is examined in studies because of its important role in the literature as an intervening variable, used to explain different levels of performance (Milani, 
1975). In most cases, attitude towards work is offered as an intervening factor that leads to better performance (Milani, 1975).

The creation of high involvement systems has been important for the strategic management of human resources (Oliveira and Rocha, 2017). Thus, the effects of job involvement on individual attitudes and behaviors of subordinates in organizations (Jiang, Lepak, Hu, \& Baer, 2012a) have been researched in the literature on the strategic management of the human resources of organizations and are elements that are reflected in performance.

In this research, it is understood that when controllers are more involved in the work, it can be assumed that these professionals develop proactive managerial attitudes towards the budget, which can result in better managerial performance. Thus, under conditions of higher levels of budgetary participation, it is understood that when they are more involved in their work these professionals will be more likely to develop such attitudes, leading to the third research hypothesis: $H_{3}$ : Job involvement is positively associated with management attitudes related to the budget.

Concerning the relationship between managerial attitudes and performance, Milani (1975) found positive and significant correlations between budget participation and attitudes towards work, while Mia (1988) found that the managerial attitude moderates the effect of participation on performance. In this case, a more favorable attitude or motivation in combination with participation in the budget process was positively associated with improved performance (Mia, 1988).

Participation in the budget process has often been postulated to have a positive effect on managerial attitudes and performance (Govindarajan, 1986). However, their effects on performance are not always straightforward (Derfuss, 2016; Dani et al., 2017). This is because the mental states of individuals influence their actions, determining how they will behave. As a result, they tend to affect their managerial performance, positively or negatively.
Thus, it is understood that under conditions of greater levels of participation and involvement of the controllers in the work, it becomes possible to identify a positive relationship between their managerial attitudes towards the budget and their performance, leading to the fourth hypothesis tested in this research: $H_{4}$ : Management attitudes are positively associated with managerial performance.

\subsection{Work Involvement, Vertical Information Sharing, and Management Performance}

Budget participation gives subordinates the opportunity to interact and communicate with their superiors and to influence their budgetary objectives (Lau and Tan, 2003). Studies such as those by Miller and Monge (1986) and Comerford and Abernethy (1999) suggest that the benefits of involving managers in the budgeting process derive primarily from the exchange and dissemination of work-relevant information in order to facilitate decision making.

Shields and Shields (1998) consider that budget participation exists to share information between superiors and subordinates, to coordinate interdependencies, and to motivate and influence attitudes. Involvement of the subordinate in the budget process can increase as well as diminish a manager's communication with the immediate supervisor (Francis-Gladney, 2004).

The subordinate's participation in the budget setting affects work-related outcomes, such as managerial performance (Murray, 1990), which leads to increased motivation and commitment to the budget (Brownell and McInnes, 1986). From a cognitive perspective, budget participation is seen to improve the flow of information between superiors and subordinates, leading to higher quality decisions (Shields and Young, 1993).

According to Fisher, Frederickson, and Peffer (2002), budgeting is an important tool for planning and motivating subordinate performance. Research suggests that subordinate participation in the budget process has two 
cognitive aspects: participation increases the quality of the budget and thus the utility of budgets, allowing subordinates to introduce their knowledge into the budget process, and participation provides the subordinate with information relevant to their work performance (Magner, Welker, and Campbell, 1996).

According to Oliveira and Rocha (2017) and Jiang et al. (2012a), performance appraisal systems, performance-related rewards, and the opportunity for career development and internal mobility promote employee motivation and effort. Thus, it is important for organizations to create policies for employee involvement and information sharing (Jiang et al., 2012a, 2012b), in order to enhance their performance.

Under these conditions, it is understood that the controller, when involved in the organization's budget processes, becomes more likely to share information with his/her superiors. Thus, in the fifth research hypothesis, it is established that: H5: Job involvement is positively associated with the vertical sharing of information.

Studies have found that budget participation is positively associated with workrelevant information (Chong and Chong, 2002; Shields and Shields, 1998; Magner et al., 1996). For Christensen (1982), budget participation may have a positive value when the communication structure is used to assess worker performance. According to Baiman and Evans (1983), budget participation allows subordinate information to be incorporated into the performance appraisal system.

As Shields and Shields (2008) explain, there are reasons for the existence of budget participation, the main ones being the sharing of information, motivation, and attitude. The involvement of subordinates in the budgeting process gives them the opportunity to access information (Baiman and Evans, 1983), which also allows them to communicate or reveal some of their private information, which can be incorporated into performance standards (Baiman and Evans, 1983).

Budget communication between a manager and a supervisor exists when the manager conveys information relevant to the budget or receives it from the supervisor (FrancisGladney, 2004). Thus, budget participation can be defined as the extent to which a manager has the opportunity to express opinions and influence the budget process (Brownell, 1982). A second general reason why organizations seek greater budget communication between managers and their superiors is its potential positive effect on attitudes, morale, and motivation related to managers' work and, in turn, behaviors such as job performance (Shields and Shields, 1998; Shields and Young, 1993).

Studies suggest that participation in the budget plays an important role in information exchange (Brownell and Dunk, 1991). However, not all individuals are likely to socialize their information. Hopwood (1976) emphasized that participation is an information-sharing mechanism from which individual employees obtain more information about their work. This information facilitates a clearer understanding of their work, thus improving their managerial performance (Mia, 1989).

Hence, it can be assumed that under conditions of greater budgetary participation, where controllers are more involved with the work, they are more likely to share information with their superiors, which may positively affect their managerial performance. Thus, the sixth research hypothesis states that: H6: Vertical information sharing is positively associated with managerial performance.

Figure 1 shows a summary of the relationships investigated in this research, based on the theoretical model of analysis developed for the study. 


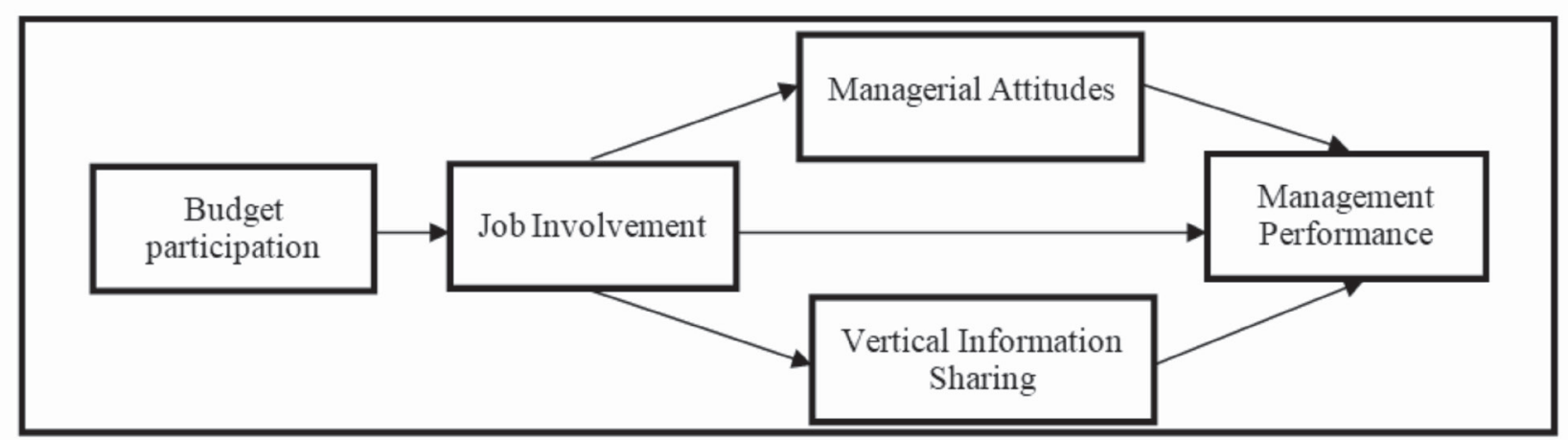

Figure 1 - Theoretical Analysis Model

Legend: BP. Budgetary Participation; JI. Job Involvement; VIS. Vertical Information Sharing; MA. Management Attitudes; MP. Management Performance.

* Significance level found: $\mathrm{p}<0.01$.

Source: survey data.

\section{Method and research procedures}

The methodology used in this research is characterized as descriptive, the process used for data collection is the survey, and the approach used for analyzing the data is quantitative. Martins and Theóphilo (2009) emphasize that quantitative research presents the data and evidence collected in a quantified and measured form. Quantitative research has clearly specified hypotheses and operationally defined variables and is concerned with the objective measurement and quantification of results (Godoy, 1995).

The population that is the object of this research consists of professionals responsible for controlling in companies that operate in Brazil, with budgetary responsibility in the organizations in which they operate. In a survey carried out using the Linkedin business network, professionals with such characteristics were identified, with functions denominated as: controllers, controller managers, and controller coordinators.

The population was defined by identifying the companies in operation in the country that have managers with such functions. This population was chosen because controllers assume different positions in different companies, which makes them a strategic piece within organizations since these professionals play a key role in the information generated in organizations (Siqueira and Soltelinho, 2001).

To define the sample to be investigated in the research, with the help of groups in Linkedin, individuals with budgetary responsibility at the national level who performed these functions were contacted in the period from November 2016 to March 2017. Initially, an invitation was sent to the controller, in which the purposes of the research were presented and his/her participation in the study was requested. Sending the invitations before the research instrument meant that when the participants received the questionnaire they were aware of what was involved and could respond with greater precision and quality to the research questions. Thus, after they accepted the invitation, the questionnaire was sent to the controllers who showed an interest in voluntarily participating in the survey.

The analyzed sample is characterized as non-probabilistic, intentional, and obtained by accessibility, and counted on the voluntary participation of 318 controllers from different organizations based in the country. A total of 1985 invitations were sent, and 852 professionals accepted to answer the research instrument. However, by the deadline set for data collection, only 318 had done so. Thus, the analyzed sample represents $37.32 \%$ of the total potential 
respondents of the research. As ethical procedures adopted, the participants were assured of their anonymity and that of the organization in which they operate.
For the data collection, a questionnaire was elaborated, with objective questions contemplating the variables analyzed in the study. Table 1 shows the variables used in the study, their operationalization, and definition.

Table 1

Constructs, operationalization, and definition of research variables

\begin{tabular}{|c|c|c|c|}
\hline Variables & Operationalization & Definition & Authors \\
\hline $\begin{array}{l}\text { Budgetary } \\
\text { Participation (BP) }\end{array}$ & $\begin{array}{l}\text { Evaluates the influence } \\
\text { an individual has on the } \\
\text { budget process }\end{array}$ & $\begin{array}{l}\text { Budgetary participation allows subordinates to } \\
\text { communicate or disclose some of their information, } \\
\text { which can be combined into budgets (Dunk, 1993). } \\
\text { Thus, budget participation strengthens the quality of the } \\
\text { budget, as it provides subordinates with an opportunity } \\
\text { to communicate relevant information in budget decisions } \\
\text { (Parker and Kyj, 2006; Kyj and Parker, 2008). }\end{array}$ & Milani (1975) \\
\hline $\begin{array}{l}\text { Job Involvement } \\
\text { (JI) }\end{array}$ & $\begin{array}{l}\text { Determines the degree } \\
\text { of involvement of the } \\
\text { subordinate with his/her } \\
\text { work }\end{array}$ & $\begin{array}{l}\text { Work-related attitude, which refers to the relative } \\
\text { strength of employees' emotional attachment, } \\
\text { identification, and involvement with their employing } \\
\text { organization (Macinati and Rizzo, 2016). }\end{array}$ & $\begin{array}{l}\text { Moynihan and Pandey } \\
\qquad(2007)\end{array}$ \\
\hline $\begin{array}{l}\text { Vertical } \\
\text { Information } \\
\text { Sharing (VIS) }\end{array}$ & $\begin{array}{l}\text { Determines the degree } \\
\text { to which subordinates } \\
\text { communicate information } \\
\text { about local conditions to } \\
\text { their superiors }\end{array}$ & $\begin{array}{l}\text { Vertical information sharing exists when valuable } \\
\text { information is spread throughout the organization. } \\
\text { When information sharing does not occur, one } \\
\text { individual may have more information than another, and } \\
\text { none can have a complete set of information (Clarkson, } \\
\text { Jacobsen, and Batcheller, 2007). }\end{array}$ & Parker and Kyj (2006) \\
\hline $\begin{array}{l}\text { Managerial Attitude } \\
\text { (MA) }\end{array}$ & $\begin{array}{l}\text { Evaluates the attitudes of } \\
\text { subordinates to managerial } \\
\text { activities }\end{array}$ & $\begin{array}{l}\text { The cognitive management attitude tends to be more } \\
\text { favorable in organizations that use the budget as part of } \\
\text { the management control strategy (Merchant, 2007). }\end{array}$ & $\begin{array}{l}\text { Adapted research } \\
\text { instrument developed } \\
\text { by Merchant (2007) }\end{array}$ \\
\hline $\begin{array}{l}\text { Management } \\
\text { Performance (MP) }\end{array}$ & $\begin{array}{l}\text { Verifies the performance of } \\
\text { managers with budgetary } \\
\text { responsibility in their work } \\
\text { activities, analyzed by the } \\
\text { respondent him/herself. }\end{array}$ & $\begin{array}{l}\text { Employees understand the impact of their actions } \\
\text { on performance measures, align their actions with } \\
\text { organizational strategy, and thus achieve performance at } \\
\text { work (Kaplan and Atkinson, 1998). }\end{array}$ & $\begin{array}{l}\text { Mahoney, Jerde, and } \\
\text { Carroll }(1963,1965) \text {, } \\
\text { in the version proposed } \\
\text { by Zonatto (2014). }\end{array}$ \\
\hline
\end{tabular}

Source: Own elaboration.

Before the hypothesis tests, the internal validity, unidimensionality, discriminant validity, reliability coefficient, and average variance extracted of each variable used in the study were analyzed. The validity and unidimensionality were tested using confirmatory factor analysis (CFA), using t-values, to make inferences regarding the hypotheses of the research, as well as chi-squared, degrees of freedom (df), a chi ${ }^{2} /$ degree of freedom (df) of less than 5, coefficient of determination $\left(\mathrm{R}^{2}\right)$, mean square root of the approximation error (RMSEA), with acceptable values between 0.03 and 0.08 , comparison of fit index (CFI) and goodness of fit index (GFI), with ideal values closer to 1 (Miles and Shevlin, 2007), to make inferences about the quality of fit of the model.

The discriminant validity was tested by comparing the variables with free correlations between the variables and fixed at 1 . The chisquared difference between the comparisons of the variables, when greater than 10,870 , indicates the discriminant validity among the variables analyzed (Stratman and Roth, 2002; Koufteros, 1999). For reliability, the variables should have a Cronbach's alpha and composite reliability equal to or greater than 0.7 and an AVE equal to or greater than 0.5 (Gudergan, Ringle, Wende, and Will, 2008). 
Since the level of analysis in this research focuses on individuals, based on the minimum number of controllers participating in the study, structural equation modeling was used to evaluate the theoretical relationships observed with the aid of the SPSS software (AMOS version 22). Hair Jr. et al. (2005) argue that for the use of structural equations, five respondents are necessary per indicator analyzed in the model. This minimum number of respondents was observed in this study. In order to reduce the constraints of the sample analyzed in the study, the model needed to be purified, eliminating indicators that have a low significance in the construct, in order to enable robustness of the analyses (Ringle, Sarstedt, and Straub, 2012; Gudergan et al., 2008).

\section{Presentation and analysis of results}

The data analysis was based on the operationalization of the theoretical model of analysis developed for the research (Figure 1), which determines relationships between budget participation, job involvement, vertical information sharing, managerial attitudes, and managerial performance. The model was implemented with the aid of structural equation modeling (SEM) to examine the hypotheses proposed in the research.

After the data collection, it was verified that the research comprised 318 controllers from different organizations. The controller position covered the largest number of respondents in the study, totaling 239 respondents. The position of controller coordinator had 40 respondents, and controller manager had 39, which represents $12.26 \%$ of the sample analyzed.

Table 2

\section{Description of the positions of the research participants and areas to which they are linked}

\begin{tabular}{lcc}
\hline Job description & $\begin{array}{c}\text { Absolute } \\
\text { Freq. }\end{array}$ & $\begin{array}{c}\text { Relative } \\
\text { Freq. }\end{array}$ \\
\hline Controller & 239 & $75,16 \%$ \\
Controller manager & 40 & $12,58 \%$ \\
Controller Coordinator & 39 & $12,26 \%$ \\
Total & $\mathbf{3 1 8}$ & $100 \%$ \\
\hline
\end{tabular}

Source: prepared by the author (2017)

Initially, a descriptive analysis was carried out of the items that compose the variables analyzed in the study, seeking to verify the data trend and reliability (Table 3 ). 
Table 3

\section{Descriptive analysis of data}

\begin{tabular}{|c|c|c|c|c|c|c|c|c|c|c|c|c|c|c|c|c|c|}
\hline Var. & Ind & $\mathrm{AC}$ & Min & Max & $\mathrm{Av}$ & SD & $\mathrm{AS}$ & CT & Var. & Ind & $\mathrm{AC}$ & Min & Max & $\mathrm{Av}$ & SD & AS & CT \\
\hline \multirow{6}{*}{ BP } & BP 1 & \multirow{6}{*}{0,85} & 1 & 7 & 6,49 & 1,07 & $-2,78$ & 8,75 & \multirow{5}{*}{ MA } & MA 1 & \multirow{5}{*}{0,85} & 1 & 5 & 4,57 & 0,64 & $-1,53$ & 2,76 \\
\hline & $\mathrm{BP} 2$ & & 1 & 7 & 5,74 & 1,43 & $-1,20$ & 1,05 & & $\overline{\mathrm{MA} 2}$ & & 1 & 5 & 4,15 & 0,92 & $-1,03$ & 0,71 \\
\hline & $\mathrm{BP} \_3$ & & 1 & 7 & 6,44 & 0,99 & $-2,51$ & 7,95 & & $\mathrm{MA}_{3} 3$ & & 1 & 5 & 4,25 & 0,86 & $-1,11$ & 1,04 \\
\hline & $\mathrm{BP} 4$ & & 1 & 7 & 6,11 & 1,23 & $-1,72$ & 3,22 & & $\mathrm{MA} 4$ & & 1 & 5 & 4,44 & 0,76 & $-1,62$ & 3,36 \\
\hline & BP 5 & & 1 & 7 & 6,42 & 0,97 & $-2,59$ & 8,94 & & MA 5 & & 1 & 5 & 4,45 & 0,71 & $-1,38$ & 2,58 \\
\hline & BP 6 & & 1 & 7 & 5,96 & 1,32 & $-1,61$ & 2,55 & \multirow{9}{*}{ MP } & MP 1 & \multirow{9}{*}{0,88} & 1 & 7 & 5,92 & 0,93 & $-1,03$ & 2 \\
\hline \multirow{3}{*}{ IW } & IW 1 & \multirow{3}{*}{0,79} & 1 & 7 & 5,62 & 1,27 & $-0,94$ & 0,77 & & $\overrightarrow{\mathrm{MP}} 2$ & & 1 & 7 & 5,93 & 0,95 & $-1,2$ & 3,04 \\
\hline & IW 2 & & 1 & 7 & 4,44 & 1,44 & $-0,43$ & 0,17 & & MP 3 & & 1 & 7 & 6,02 & 0,91 & $-0,68$ & $-0,21$ \\
\hline & IW 3 & & 1 & 7 & 4,29 & 1,56 & $-0,32$ & $-0,41$ & & MP 4 & & 1 & 7 & 5,75 & 1 & $-0,63$ & 0,08 \\
\hline \multirow{5}{*}{ VIS } & VIS 1 & \multirow{3}{*}{0,84} & 1 & 7 & 6,10 & 1,13 & $-1,88$ & 4,58 & & MP 5 & & 1 & 7 & 6,08 & 0,97 & $-1,31$ & 2,49 \\
\hline & VIS 2 & & 1 & 7 & 6,21 & 1,09 & $-2,23$ & 6,42 & & MP 6 & & 1 & 7 & 5,84 & 1,07 & $-1,1$ & 2,24 \\
\hline & VIS 3 & & 1 & 7 & 5,68 & 1,37 & $-1,35$ & 1,80 & & MP 7 & & 1 & 7 & 5,61 & 1,17 & $-1,06$ & 1,61 \\
\hline & & & & & & & & & & MP 8 & & 1 & 7 & 5,29 & 1,42 & $-0,81$ & 0,32 \\
\hline & & & & & & & & & & MP 9 & & 1 & 7 & 5,89 & 0,74 & $-0,43$ & 0,13 \\
\hline
\end{tabular}

Legend: BP. Budgetary Participation; IW. Job Involvement; VIS. Vertical Information Sharing; MA. Management Attitudes; MP. Management Performance; AC. Cronbach's Alpha; Min. Minimum; Max. Maximum; AV. Average; SD. Standard Deviation; AS. Symmetry; CT. Kurtosis;

Source: survey data.

Table 3 shows that all variables had minimum and maximum responses on the scale used, which indicated the degree of disagreement (1) or agreement (7) in relation to the statement used in the study. These results demonstrate that the controllers operate in different budget configurations. In addition, the controllers perceive their influence in budgeting processes differently. Likewise, it can be seen that not all the research participants feel involved in their work and have proactive managerial attitudes towards the budget, as it is observed that not all the controllers share information with their superiors and achieve better performance.

In order to evaluate the relationships between the constructs analyzed in the research, structural equation modeling was carried out. The results of the fit indices of the structural model evaluated in the research are presented in Table 4.
Table 4

\section{Measurement model indices}

\begin{tabular}{lcc}
\hline Indicator & $\begin{array}{c}\text { Expected } \\
\text { value }\end{array}$ & $\begin{array}{c}\text { Initial } \\
\text { Model }\end{array}$ \\
\hline $\mathrm{Chi}^{2}$ & & 931.99 \\
Degrees of Freedom - DF & $<5$ & 3.17 \\
$\mathrm{Chi}^{2} /$ Degrees of Freedom - DF & $\mathrm{p}<0.05$ & 0.000 \\
Statistical significance - P & $>0.90$ & 0.848 \\
Comparative Fit Index - CFI & $>0.90$ & 0.817 \\
Goodness of Fit Index - GFI & $<0.10$ & 0.083 \\
Root Mean Square Error of & & \\
Approximation - RMSEA & & \\
\hline
\end{tabular}

Source: survey data.

It can be seen in Table 4 that the initial measurement model elaborated for the analysis of workers involved in the budget process, regarding managerial attitudes, vertical information sharing, and managerial performance, presented 
acceptable values close to those expected, which suggests the validity of the model measurement. The adjustment index of this model presented a value of 3.17, this being significant at $\rho<0.000$. The comparative fit index (CFI) obtained a value of 0.848 , this being close to what was expected, along with the other indices analyzed in Table 4.

In order to ascertain the predictive quality of the theoretical constructs analyzed in the study, the Cronbach's alpha coefficients, the composite reliability (CR), and the average variance extracted (AVE) of each of the constructs presented in the study were evaluated. The results are shown in Table 5.

Table 5

\section{Dimensional Reliability Analysis}

\begin{tabular}{lccc}
\hline Dimensions & Composite Reliability & Variance Extracted & Cronbach's Alpha \\
\hline Budget Participation & 0,86 & 0,61 & 0,852 \\
Job Involvement & 0,81 & 0,59 & 0,795 \\
Management Attitudes & 0,87 & 0,57 & 0,856 \\
Vertical Information Sharing & 0,86 & 0,67 & 0,843 \\
Management Performance & 0,86 & 0,55 & 0,886 \\
\hline
\end{tabular}

Source: survey data.

It is observed that the variables analyzed in the study presented reliability coefficients that are considered adequate by the literature. The Cronbach's alpha (CA) of the final measurement constructs selected for the survey were higher than 0.795 . The composite reliability (CR) also showed values higher than 0.7 , with the lowest value found being 0.81 . In turn, the variance extracted (AVE) indicates that all constructs had values higher than 0.55 .
The discriminant validity analysis of the variables tested in the model was performed according to the procedures recommended by Fornell and Larcker (1981). Thus, we evaluated the shared variances, where the variances extracted from the constructs are compared with the shared variance (Eberle, Milan, and Matos, 2016). The results found are shown in Table 6.

Table 6

Discriminant validity of variables

\begin{tabular}{|c|c|c|c|c|c|}
\hline \multicolumn{6}{|c|}{ Correlation of constructs with AVE } \\
\hline & BP & JI & MA & VIS & MP \\
\hline $\mathrm{BP}$ & 0,54 & - & - & - & - \\
\hline JI & 0,20 & 0,67 & - & & - \\
\hline MA & 0,00 & 0,26 & 0,67 & - & - \\
\hline VIS & 0,00 & 0,33 & 0,00 & 0,43 & - \\
\hline MP & 0,00 & 0,14 & 0,30 & 0,45 & 0,50 \\
\hline \multicolumn{6}{|c|}{ Discriminant validity using the criterion of Fornell and Larcker (1981) } \\
\hline & $\mathbf{B P}$ & JI & MA & VIS & MP \\
\hline $\mathrm{BP}$ & 0,54 & - & - & - & - \\
\hline JI & 0,04 & 0,67 & - & - & - \\
\hline MA & 0,00 & 0,07 & 0,67 & - & - \\
\hline VIS & 0,00 & 0,11 & 0,00 & 0,43 & - \\
\hline MP & 0,00 & 0,02 & 0,09 & 0,20 & 0,50 \\
\hline
\end{tabular}

Source: survey data. 
As shown in Table 6, it can be seen from the discriminant validity test suggested by Fornell and Larcker (1981) that the variance extracted from the analyzed variables is higher than the shared variance of the analyzed constructs, which indicates their discriminant validity. Thus, we analyzed the theoretical relationships investigated in the research, based on the results found in the structural model tested, in order to accept or reject the hypotheses established for the study. Figure 2 shows the final results of the path estimates of the measurement model used.

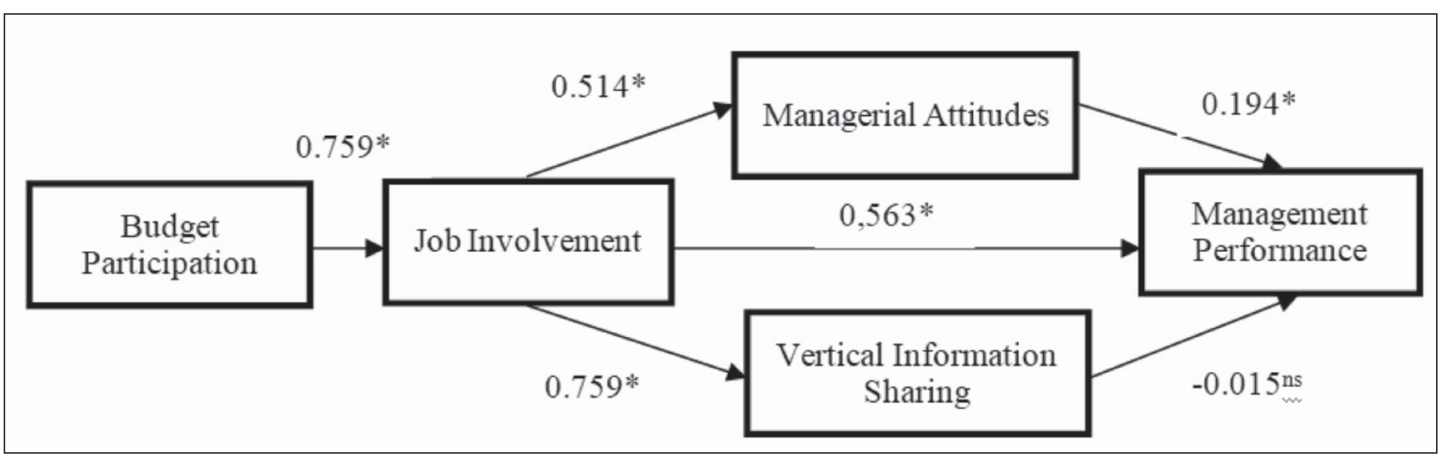

Figure 2

\section{Estimates of structural model paths}

* Significance level found: $\mathrm{p}<0.01$.

Source: survey data.

It can be seen from the results presented in Figure 2 that budget participation strengthens (increases) job involvement, resulting in better managerial performance. Similarly, it can be seen that in conditions of higher levels of job involvement there is an increase in vertical information sharing and managerial attitudes, which results in better controller performance. Therefore, it can be verified that job involvement constitutes a conditioning variable for obtaining better managerial performance in the budget context. The standardized coefficients and significance of the relationships in this model are presented in Table 7.

Table 7

\section{Standardized coefficients and significance of the relationships of the models tested}

\begin{tabular}{|c|c|c|c|c|c|c|c|c|c|}
\hline \multicolumn{10}{|c|}{ Model Results } \\
\hline \multicolumn{3}{|c|}{ Structural Pathways } & \multirow{2}{*}{$\begin{array}{c}\text { Hypotheses } \\
\mathrm{H}_{1}\end{array}$} & \multirow{2}{*}{$\begin{array}{c}\text { Estimate } \\
0,294\end{array}$} & \multirow{2}{*}{$\begin{array}{c}\text { E.P. } \\
0,064\end{array}$} & \multirow{2}{*}{$\frac{t \text {-values }}{4,557}$} & \multirow{2}{*}{$\begin{array}{c}\rho \\
* * *\end{array}$} & \multirow{2}{*}{$\begin{array}{c}\text { Standardized } \\
\text { Coefficient }\end{array}$} & \multirow{2}{*}{$\begin{array}{c}\mathbf{R}^{2} \\
0,58\end{array}$} \\
\hline $\mathrm{JI}$ & $\leftarrow$ & $\mathrm{BP}$ & & & & & & & \\
\hline MA & $\leftarrow$ & JI & $\mathrm{H}_{2}$ & 0,728 & 0,176 & 4,132 & $* * *$ & 0,514 & 0,26 \\
\hline VIS & $\leftarrow$ & JI & $\mathrm{H}_{3}$ & 2,677 & 0,596 & 4,494 & $* * *$ & 0,939 & 0,88 \\
\hline MP & $\leftarrow$ & VIS & $\mathrm{H}_{4}$ & $-0,009$ & 0,080 & $-0,118$ & 0,906 & $-0,015$ & 0,45 \\
\hline MP & $\leftarrow$ & JI & $\mathrm{H}_{5}$ & 1,000 & - & - & $* * *$ & 0,563 & 0,45 \\
\hline MP & $\leftarrow$ & MA & $\mathrm{H}_{6}$ & 0,243 & 0,083 & 2,914 & 0,004 & 0,194 & 0,45 \\
\hline
\end{tabular}

Note 1: Path between MP and JI set ( $\mathrm{t}$ test not calculated).

Note 2: Levels of significance: Acceptable value: $\mathrm{p}<0.05$ - Value found: ${ }^{* * *} \mathrm{p}<0.01$

Source: survey data (2018). 
In Table 7, a positive and significant relationship can be seen between budget participation and job involvement, as well as between involvement and managerial performance. Thus, it is possible to verify the direct influence of budget participation on the job involvement of the controllers and of job involvement on their managerial performance, which confirms $\mathrm{H} 1$ : budgetary participation is positively related to job involvement, and $\mathrm{H} 2$ : job involvement is positively associated with managerial performance.

The findings of this research demonstrate that budgetary participation has a direct influence on the job involvement of the controllers. Likewise, job involvement positively and significantly influences the managerial performance of the controllers in the budget process. Thus, budget participation indirectly influences the managerial performance of controllers, based on the effects that it has on the job involvement of these professionals.

According to Chong et al. (2006), budget participation increases the confidence of subordinates as well as their involvement in their work. Regarding job involvement and managerial performance, Brown (1996) showed a non-significant relationship between engagement at work and managerial performance. However, Brown and Leigh (1996) showed a correlation between job involvement and managerial performance, thus corroborating the findings of this study.

It should be emphasized that in the model measuring the influence of job involvement on managerial attitudes, the path is $\lambda=0.514$ at $\rho<0.000$. In the influence of managerial attitudes on the managerial performance of subordinates, the path presented a value of $\lambda=0.194$ at $\rho<0.004$. Thus, it is possible to affirm that job involvement directly influences the attitudes of the managers and managerial attitudes influences the managerial performance of subordinates, which confirms hypotheses H3: job involvement is positively associated with the attitudes of subordinates, and H4: management attitudes are positively associated with managerial performance.

As Milani (1975) explains, the attitude of subordinates towards work is an intervening factor that leads to better managerial performance. In this sense, Yukl (1971) demonstrated a positive relationship between the budget participation and the managerial attitudes of subordinates. Milani (1975) also found a positive and significant correlation between budgetary participation and attitudes towards work, as evidenced in this study.

Regarding the influence of managerial attitudes on managerial performance, the results of this study corroborate with the findings of Mia (1988), who demonstrated the moderation of managerial attitudes in the effect of budgetary participation on performance. Yuen (2007) emphasized that budget participation can be most effective when staff members have a positive attitude, which will ultimately improve employee performance.

Table 7 also shows that the model for measuring the direct effects of employees involved in vertical information sharing presented a path of $\lambda=0.563$ at $\rho<0.000$. The direct effect of vertical information sharing on managerial performance was not significant, and the path was $\lambda=-0.015$ at $\rho<0.906$. Thus, it is possible to prove by the empirical evidence produced in this research that job involvement influences vertical information sharing. However, this cannot be inferred from its direct effects on managerial performance. Thus, H5 is confirmed: job involvement is positively associated with vertical information sharing, but the findings refute H6: vertical information sharing is positively associated with managerial performance.

Hence, it is observed that job involvement has a positive influence on vertical information sharing by the controllers in the Brazilian companies. These results demonstrate that the more involved the controller is with organizational processes, the greater the tendency is for him/her to be willing to share information with his/her superiors. 
However, in this research, greater vertical sharing of information did not directly imply greater managerial performance of the controllers. It is noted that even if information sharing occurs between superior and subordinate, which may result in a reduction of information asymmetry, this information sharing may not directly influence the performance of the subordinate, which suggests that other intervening variables might influence this relationship, thus constituting an opportunity to carry out new studies.

Even though this relationship is not identified as significant, it can be verified by the descriptive statistical analysis carried out that in conditions of greater participation there is greater involvement of managers and, consequently, greater sharing of information. Likewise, this involvement results in better performance. These results suggest that the effects of information sharing between superiors and subordinates can be conditioned by the ease of communication and loyalty and trust of the employees in the management of the organization, which tends to promote greater cooperation and flexibility at all managerial levels (Mia and Patiar, 2002).

In any case, it must be taken into account that this may not always make the subordinate feel more successful in the organization. Thus, it can be inferred that superior managerial performance will occur when, besides sharing information, the individuals are more involved with the work and adopt proactive managerial attitudes towards the budget.

For Magner et al. (1996), the subordinatess participation in the budget process allows him/ her to include his/her knowledge in the budget process. Shields and Shields (1998) pointed out that budget sharing exists to share information between superiors and subordinates. In addition, Francis-Gladney (2004) showed that involvement in the budget process increased as well as decreased communication between superiors and subordinates.

The results found in the study demonstrate that greater budgetary participation and greater employee involvement lead to better managerial attitudes, the vertical sharing of information, and better managerial performance of the controllers of companies operating in Brazil. Thus, it can be inferred that the greater the job involvement of these professionals, the better their managerial attitudes and the greater their willingness to share information with their superiors, which will contribute to achieving better managerial performance in the budgetary context.

\section{Final considerations}

This study investigated the intervening effects of job involvement, managerial attitudes, and information sharing in the relationship between the budget participation and managerial performance of controllers. The descriptive research was carried out through a survey of 318 respondents with budgetary responsibility in companies operating in Brazil. The data analysis was performed using a quantitative approach, employing structural equation modeling.

The results showed that budget participation positively influences job involvement, which showed a direct and indirect influence on managerial performance, mediated by the managerial attitudes of the controllers in relation to the budget. Job involvement influences controllers' managerial attitudes and their willingness to share information with superiors. These results reveal the intervening role of job involvement in the relationship between participation and performance. They reveal that the participation of controllers in the budget processes of their organizations improves their job involvement, influencing their managerial attitudes, their propensity to share information, and their performance.

These results corroborate with Yuen (2007), who revealed that attitudes towards work have been shown to be an intervening factor affecting managerial performance when subordinates participate in budget activities. Likewise, they are consistent with the findings of Milani (1975), who pointed out that attitude 
towards work is an intervening factor that leads to better managerial performance.

In this research, the evidence produced suggests that job involvement enhances such attitudes, producing these effects. Therefore, it is perceived that job involvement is an intervening factor in the budgetary context, capable of influencing the attitudes, behaviors, and performance of controllers in their work. From the behavioral perspective, this is because the effects of budget participation on managerial performance do not always occur directly, and there are intervening variables that measure this relationship (Derfuss, 2016; Dani et al., 2017).

These findings provide evidence of a relevant theoretical contribution of this research, since this variable has been neglected when carrying out studies developed under the behavioral approach to accounting that investigate the effects of budgetary participation on managerial performance, as well as other behavioral variables which affect the performance of individuals at work, such as their motivation and behavior.

Work involvement positively influences vertical information sharing. Therefore, it is a predictor for these professionals socializing private information with their superiors. In spite of this, vertical information sharing alone did not have a direct and statistically significant influence on the managerial performance of the controllers participating in the research, which reinforces the evidence that job involvement constitutes an important intervening variable in this context.

One possible explanation for these results may be related to the effects of information sharing between superiors and subordinates being conditioned by the perceptions of subordinate managers in relation to the ease of communication, loyalty, and/or trust between employees and superior management, which tends to affect levels of cooperation and flexibility at all managerial levels (Mia and Patiar, 2002). Since these elements were not investigated in this research, they constitute an opportunity for carrying out new studies.

The findings also revealed that budgetary participation enhances the job involvement of controllers, which has a direct and indirect influence on managerial performance, based on the managerial attitudes of the controllers. Likewise, these influence their willingness to information, which can enhance the information flow between the different departmental units of the organization, improving budget forecasts and the performance of managers and units of responsibility. As a result, they can help reduce conflict of interests and the levels of informational asymmetry that exist.

Thus, the findings of this research allow us to conclude that budget participation enhances the involvement of controllers with budgetary responsibility of companies operating in Brazil. This variable acts in determining how the effects of this participation on performance occur, as well as the effects of managerial attitudes in relation to the budget and the vertical sharing of information of these professionals in the budget context.

Some research opportunities under the behavioral approach in accounting can be taken from this evidence. Analyzing the effects of job involvement on occupational stress in the budget context may indicate under what conditions the dedication of individuals attenuates the negative effects of occupational stress. The same can be observed for the effects of other intervening behavioral variables, such as their psychological capacities and their personal resilience. These elements may reveal how involvement enhances performance, considering other intervening variables present in the budget process.

\section{References}

Argyris, C. (1952). The impact of budgets on People, a Study Prepared for Controllership Foundation, Inc. Ithaca, NY: Cornell University, The School of Business and Public Administration.

Baiman, S., \& Evans, J. H. (1983). Pre-decision information and participative management 
control systems. Journal of Accounting Research, 371-395.

Bakker, A. B., Schaufeli, W. B., Leiter, M. P., \& Taris, T. W. (2008). Work engagement: An emerging concept in occupational health psychology. Work \& Stress, 22(3), 187-200.

Brownell, P., \& Dunk, A. S. (1991). Task uncertainty and its interaction with budgetary participation and budget emphasis: some methodological issues and empirical investigation. Accounting, Organizations and Society, 16(8), 693-703.

Brownell, P., \& McInnes, M. (1986). Budgetary participation, motivation, and managerial performance. Accounting review, 587-600.

Brown, S. P., \& Leigh, T. W. (1996). A new look at psychological climate and its relationship to job involvement, effort, and performance. Journal of applied psychology, 81(4), 358.

Brown, S. P. (1996). A meta-analysis and review of organizational research on job involvement. Psychological bulletin, 120(2), 235.

Brownell, P., \& McInnes, M. (1986). Budgetary participation, motivation, and managerial performance. Accounting review, 587-600.

Brownell, P. (1982). The role of accounting data in performance evaluation, budgetary participation, and organizational effectiveness. Journal of accounting research, 12-27.

Bruns, W. J., \& Waterhouse, J. H. (1975). Budgetary control and organization structure. Journal of accounting research, 177-203.

Cavalcante, M. M., Siqueira, M. M. M., \& Kuniyoshi, M. S. (2015). Engajamento, bemestar no trabalho e capital psicológico: um estudo com profissionais da área de gestão de pessoas. Pensamento \& Realidade. Revista do Programa de Estudos Pós-Graduados em Administração-FEA, 29(4), 23.

Comerford, S. E., \& Abernethy, M. A. (1999). Budgeting and the management of role conflict in hospitals. Behavioral Research in Accounting, 11, 93.

Chong, V. K., \& Chong, K. M. (2002). Budget goal commitment and informational effects of budget participation on performance: A structural equation modeling approach. Behavioral Research in Accounting, 14(1), 65-86.

Chong, V. K., Eggleton, I. R., \& Leong, M. K. (2006). The multiple roles of participative budgeting on job performance. Advances in accounting, 22, 67-95.

Clarkson, G., Jacobsen, T. E., \& Batcheller, A. L. (2007). Information asymmetry and information sharing. Government Information Quarterly, 24(4), 827-839.

Covaleski, M., Evans III, J. H., Luft, J., \& Shields, M. D. (2006). Budgeting research: three theoretical perspectives and criteria for selective integration. Handbooks of management accounting research, 2, 587-624.

Christensen, J. (1982). The determination of performance standards and participation. Journal of Accounting Research, 589-603.

Christian, M. S., Garza, A. S., \& Slaughter, J. E. (2011). Work engagement: A quantitative review and test of its relations with task and contextual performance. Personnel psychology, 64(1), 89-136.

Dani, A. C., Zonatto, V. C. S., \& Diehl, C. A. (2017). Participação orçamentária e desempenho gerencial: uma meta-análise das relações encontradas em pesquisas desenvolvidas na área comportamental da contabilidade. Advances in Scientific and Applied Accounting, 10 (1).

Derfuss, K. (2016). Reconsidering the participative budgeting-performance relation: A meta-analysis 
regarding the impact of level of analysis, sample selection, measurement, and industry influences. The British Accounting Review, 48(1), 17-37.

Diefendorff, J. M., Brown, D. J., Kamin, A. M., \& Lord, R. G. (2002). Examining the roles of job involvement and work centrality in predicting organizational citizenship behaviors and job performance. Journal of Organizational Behavior, 23(1), 93-108.

Dunk, A. S. (1993). The effect of budget emphasis and information asymmetry on the relation between budgetary participation and slack. Accounting review, 400-410.

Eberle, L., Sperandio Milan, G., \& de Matos, C. A. (2016). Antecedents to customer retention in a corporate context. BBR-Brazilian Business Review, 13(1).

Fisher, J., Frederickson, J. R., \& Peffer, S. A. (2002). The effect of information asymmetry on negotiated budgets: An empirical investigation. Accounting, Organizations and Society, 27(1-2), 27-43.

Francis-Gladney, L., Little, H. T., Magner, N. R., \& Welker, R. B. (2004). Does OrganizationMandated Budgetary Involvement Enhance Managers' budgetary Communication With Their Supervisor? In Advances in Management Accounting (pp. 167-182). Emerald Group Publishing Limited.

Fornell, C., \& Larcker, D. F. (1981). Structural equation models with unobservable variables and measurement error: Algebra and statistics. Journal of marketing research, 382-388.

Godoy, A. S. (1995). Introdução à pesquisa qualitativa e suas possibilidades. In: Revista de Administração de Empresas. São Paulo: 35 (2), 57-63.Govindarajan, V. (1986). Impact of participation in the budgetary process on managerial attitudes and performance: Universalistic and contingency perspectives. Decision Sciences, 17(4), 496-516.
Govindarajan, V. (1989). Implementing competitive strategies at the business unit level: Implications of matching managers to strategies. Strategic Management Journal, 10(3), 251-269.

Gudergan, S. P., Ringle, C. M., Wende, S., \& Will, A. (2008). Confirmatory tetrad analysis in PLS path modeling. Journal of business research, 61(12), 1238-1249.

Hannan, R. L., Rankin, F. W., \& Towry, K. L. (2010). Flattening the organization: The effect of organizational reporting structure on budgeting effectiveness. Review of Accounting Studies, 15(3), 503-536.

Hair Jr, J. F., Anderson, R. E., Tatham, R. L., \& Black, W. C. (2005). Análise Multivariada de dados. Translation: Adonai Schlup Sant 'Anna \& Anselmo Chaves Neto.

Hopwood, A. G. (1972). An empirical study of the role of accounting data in performance evaluation. Journal of accounting research, 156-182.

Ivancevich, J. M. (1976). Effects of goal setting on performance and job satisfaction. Journal of Applied Psychology, 61(5), 605.

Jiang, K., Lepak, D. P., Hu, J., \& Baer, J. C. (2012a). How does human resource management influence organizational outcomes? A meta-analytic investigation of mediating mechanisms. Academy of management Journal, 55(6), 1264-1294.

Jiang, K., Lepak, D. P., Han, K., Hong, Y., Kim, A., \& Winkler, A. L. (2012b). Clarifying the construct of human resource systems: Relating human resource management to employee performance. Human resource management review, 22(2), 73-85.

Kanungo, R. N. (1982). Measurement of job and work involvement. Journal of applied psychology, 67(3), 341. 
Kaplan, R. S., Atkinson, A. A., \& Morris, D. J. (1998). Advanced management accounting (Vol. 3). Upper Saddle River, NJ: Prentice Hall.

Katz, D., \& Kahn, R. L. (1978). The social psychology of organizations (Vol. 2, p. 528). New York: Wiley.

Kenis, I. (1979). Effects of budgetary goal characteristics on managerial attitudes and performance. Accounting Review, 707-721.

Koufteros, X. A. (1999). Testing a model of pull production: a paradigm for manufacturing research using structural equation modeling. Journal of Operations Management, 17(4), 467-488

Lau, C. M., \& Lim, E. W. (2002). The intervening effects of participation on the relationship between procedural justice and managerial performance. The British Accounting Review, 34(1), 55-78.

Lau, C. M., \& Tan, S. L. (2003). The effects of participation and job-relevant information on the relationship between evaluative style and job satisfaction. Review of Quantitative Finance and Accounting, 21(1), 17-34.

Lavarda, C. E. F., \& Fank, O. L. (2014). Relação da assimetria da informação, da participação orçamentária e do risco na criação da folga orçamentária. CONTEXTUS - Revista Contemporânea de Economia e Gestão, 12(1), 81110.

Lawler III, E. E. (1986). High-Involvement Management. Participative Strategies for Improving Organizational Performance. Jossey-Bass Inc., Publishers, 350 Sansome Street, San Francisco, CA 94104.

Libby, T., \& Lindsay, R. M. (2010). Beyond budgeting or budgeting reconsidered? A survey of North-American budgeting practice. Management accounting research, 21(1), 56-75.
Macinati, M. S., \& Rizzo, M. G. (2016). Exploring the link between clinical managers involvement in budgeting and performance: Insights from the Italian public health care sector. Health care management review, 41(3), 213-223.

Magner, N., Welker, R. B., \& Campbell, T. L. (1996). Testing a model of cognitive budgetary participation processes in a latent variable structural equations framework. Accounting and Business Research, 27(1), 41-50.

Merchant, K. A. (2007). O modelo do sistema de orçamento corporativo: influências no comportamento e no desempenho gerencial. Revista de Contabilidade e Organizaçóes, 1(1), 107.

Mahoney, T. A., Jerde, T. H., \& Carroll, S. J. (1963). Development of managerial performance: a research approach. Cincinnati: South-Western.

Mahoney, T. A., Jerde, T. H., \& Carroll, S. J. (1965). The jobs of management. Industrial Relations, 4, 97-110.

Martins, G. D. A., \& Theóphilo, C. R. (2009). Metodologia da investigação cientifica. São Paulo: Atlas.

Mia, L. (1988). Managerial attitude, motivation and the effectiveness of budget participation. Accounting, Organizations and Society, 13(5), 465-475.

Mia, L. (1989). The impact of participation in budgeting and job difficulty on managerial performance and work motivation: a research note. Accounting, Organizations and Society, 14(4), 347-357.

Mia, L., \& Patiar, A. (2002). The interactive effect of superior-subordinate relationship and budget participation on managerial performance in the hotel industry: an exploratory study. Journal of Hospitality \& Tourism Research, 26(3), 235-257.

Milani, K. (1975). The relationship of participation in budget-setting to industrial 
supervisor performance and attitudes: a field study. The accounting review, 50(2), 274-284.

Miles, J., \& Shevlin, M. (2007). A time and a place for incremental fit indices. Personality and individual differences, 42(5), 869-874.

Miller, K. I., \& Monge, P. R. (1986). Participation, satisfaction, and productivity: A meta-analytic review. Academy of management Journal, 29(4), 727-753.

Moynihan, D. P., \& Pandey, S. K. (2007). Finding workable levers over work motivation: Comparing job satisfaction, job involvement, and organizational commitment. Administration \& Society, 39(7), 803-832.

Murray, D. (1990). The performance effects of participative budgeting: An integration of intervening and moderating variables. Behavioral Research in Accounting, 2(2), 104-123.

Oliveira, L. B. D., \& Rocha, J. D. C. (2017). Work engagement: Individual and situational antecedents and its relationship with turnover intention. Revista brasileira de gestão de negócios, 19(65), 415-431.

Parker, R. J., \& Kyj, L. (2006). Vertical information sharing in the budgeting process. Accounting, Organizations and Society, 31(1), 27-45.

Ringle, C. M., Sarstedt, M., \& Straub, D. W. (2012). Editor's Comments: A Critical Look at the Use of PLS-SEM in” MIS Quarterly”. MIS quarterly, iii-xiv.

Santos, A. C., Marcello, I. E., \& Lavarda, C. E. F. (2014). Relação do conhecimento de gestão de custos e participação orçamentária com o desempenho dos gestores. Revista brasileira de gestão de negócios, 16(50), 124-142.

Sathe, V. (1983). The controller role in management. Organizational Dynamics, 2, 31-48.
Shields, J. F., \& Shields, M. D. (1998). Antecedents of participative budgeting. Accounting, Organizations and Society, 23(1), 49-76.

Shields, M. D., \& Young, S. M. (1993). Antecedents and consequences of participative budgeting: evidence on the effects of asymmetrical information. Journal of Management Accounting Research, 5, 265.

Siqueira, M. M. M. (2008). Envolvimento com o trabalho. Medidas do comportamento organizacional: ferramentas de diagnóstico e de gestão, 139-143.

Siqueira, J. R. M. D., \& Soltelinho, W. (2001). O profissional de controladoria no mercado brasileiro: do surgimento da profissão aos dias atuais. Revista Contabilidade \& Finanças, 12(27), 66-77.

Sponem, S., \& Lambert, C. (2010). Pratiques budgétaires, rôles et critiques du budget. Perception des DAF et des contrôleurs de gestion. Comptabilité-Contrôle-Audit, 16(1), 159-194.

Stratman, J. K., \& Roth, A. V. (2002). Enterprise resource planning (ERP) competence constructs: two-stage multi-item scale development and validation. Decision Sciences, 33(4), 601-628.

Vandenberg, R. J., Richardson, H. A., \& Eastman, L. J. (1999). The impact of high involvement work processes on organizational effectiveness: A second-order latent variable approach. Group \& Organization Management, 24(3), 300-339.

Yuen, D. (2007). Antecedents of budgetary participation: enhancing employees' job performance. Managerial AuditingJournal, 22(5), 533-548.

Yukl, G. (1971). Toward a behavioral theory of leadership. Organizational behavior and human performance, 6(4), 414-440. 
Zonatto, V. C. S. (2014). Influência de fatores sociais cognitivos de capacidade, vontade e oportunidade sobre o desempenho gerencial nas atividades orçamentárias das maiores empresas exportadoras do Brasil. 332 f. Thesis (PhD in Accounting and Business) - Programa de Pós-Graduação em Ciências Contábeis da Universidade Regional de Blumenau, Blumenau.

\section{Acknowledgements:}

To the Coordination for the Improvement of Higher Education Personnel (CAPES) and to the National Council for Scientific and Technological Development (CNPq). Article related to the Project "Research on managerial performance of managers with budgetary responsibility" (Case No: 472195 / 2014-0). 


\section{Research Instrument Used in Data Collection:}

\section{Block 1 - Budgetary Participation}

The statements below are related to managers and their "Budgetary Participation" in the company where they work. Please indicate the extent to which you disagree with or agree with the statements below. The degree of agreement varies between (1) strongly disagree and (7) totally agree.

\begin{tabular}{|c|c|c|c|c|c|c|c|c|}
\hline \multirow{2}{*}{ N. } & \multirow{2}{*}{ Statements about Budgetary Participation } & \multicolumn{4}{|c|}{ Strongly disagree } & \multicolumn{3}{|c|}{ Totally agree } \\
\hline & & 1 & 2 & 3 & 4 & 5 & 6 & 7 \\
\hline BP_01 & I'm totally involved in budgeting for my unit. & & & & & & & \\
\hline BP_02 & $\begin{array}{l}\text { My superior provides ample information when my unit's budget is } \\
\text { reviewed. }\end{array}$ & & & & & & & \\
\hline BP_03 & $\begin{array}{l}\text { In preparing the budget for my unit I have autonomy to express } \\
\text { opinions or make suggestions on the budget to my superior, even } \\
\text { without being asked. }\end{array}$ & & & & & & & \\
\hline BP_04 & I have considerable influence on the final budget for my unit. & & & & & & & \\
\hline BP_05 & $\begin{array}{l}\text { I believe my contribution to the budget process in my unit is } \\
\text { considerable. }\end{array}$ & & & & & & & \\
\hline BP_06 & $\begin{array}{l}\text { Regarding the budget for my unit, I am frequently sought by my } \\
\text { superior to exchange information and give opinions and suggestions on } \\
\text { the forecasts made. }\end{array}$ & & & & & & & \\
\hline
\end{tabular}

\section{Block 2 - Job Involvement}

The statements below are related to managers and their "Job Involvement" in the company where they work. Please indicate the extent to which you disagree with or agree with the statements below. The degree of agreement varies between (1) strongly disagree and (7) totally agree.

\begin{tabular}{|c|c|c|c|c|c|c|c|c|}
\hline \multirow{2}{*}{ N. } & \multirow{2}{*}{ Statements about Job Involvement } & \multicolumn{3}{|c|}{ Strongly disagree } & \multicolumn{4}{|c|}{ Totally agree } \\
\hline & & 1 & 2 & 3 & 4 & 5 & 6 & 7 \\
\hline IW_01 & The most important things I do involve my work. & & & & & & & \\
\hline IW_02 & I like my job more than anything else I do. & & & & & & & \\
\hline IW_03 & The greatest satisfaction in my life comes from my work. & & & & & & & \\
\hline
\end{tabular}

\section{Block 3 - Vertical Information Sharing}

The statements below are related to "Information Sharing" in the company where you work. Please indicate the extent to which you disagree with or agree with the statements below. The degree of agreement varies between (1) strongly disagree and (7) totally agree.

\begin{tabular}{|c|c|c|c|c|c|c|c|c|}
\hline \multirow{2}{*}{ N. } & \multirow{2}{*}{ Statements about Vertical Information Sharing } & \multicolumn{4}{|c|}{ Strongly disagree } & \multicolumn{3}{|c|}{ Totally agree } \\
\hline & & 1 & 2 & 3 & 4 & 5 & 6 & 7 \\
\hline VIS_01 & $\begin{array}{l}\text { I share my ideas with my superior about the situation in my area of } \\
\text { responsibility. }\end{array}$ & & & & & & & \\
\hline VIS_02 & $\begin{array}{l}\text { I communicate information to my superiors about the opportunities and } \\
\text { problems facing the organization. }\end{array}$ & & & & & & & \\
\hline VIS_03 & $\begin{array}{l}\text { Information is shared with superiors who help deal with problems in } \\
\text { the organization (for example, to learn about better ways to carry out } \\
\text { activities). }\end{array}$ & & & & & & & \\
\hline
\end{tabular}




\section{Block 5 - Management Attitudes}

The following statements are related to "Manager Attitudes" in the company where you work. Please indicate the extent to which you disagree with or agree with the statements below. The degree of agreement varies between (1) strongly disagree and (7) totally agree.

\begin{tabular}{|c|c|c|c|c|c|c|c|c|}
\hline \multirow[t]{2}{*}{ N. } & \multirow[t]{2}{*}{ Statements about Managerial Attitudes } & \multicolumn{3}{|c|}{$\begin{array}{l}\text { Strongly } \\
\text { disagree }\end{array}$} & \multicolumn{4}{|c|}{ Totally agree } \\
\hline & & 1 & 2 & 3 & 4 & 5 & 6 & 7 \\
\hline MA_01 & I believe that budgeting allows me to be a better manager. & & & & & & & \\
\hline MA_02 & I believe that the budget allows me to be more flexible. & & & & & & & \\
\hline MA_03 & I believe that the budget allows me to be more innovative. & & & & & & & \\
\hline MA_04 & $\begin{array}{l}\text { I believe that the budget allows me to be attentive to my successes as a } \\
\text { manager. }\end{array}$ & & & & & & & \\
\hline MA_05 & I believe that budgeting allows me to improve my production methods. & & & & & & & \\
\hline
\end{tabular}

\section{Block 6 - Management Performance at Work}

The following activities are related to the "Managerial Performance at Work" of the managers participating in the research. Please self-evaluate your performance in comparison with your peers, based on each of the activities (tasks) specified below. The self-assessment scale ranges from [1] below-average performance to [7] above-average performance.

\begin{tabular}{|c|c|c|c|c|c|c|c|c|}
\hline \multirow[t]{2}{*}{ N. } & \multirow[t]{2}{*}{ Activities involving Management Performance at Work } & \multicolumn{3}{|c|}{$\begin{array}{l}\text { Below Average } \\
\text { Performance }\end{array}$} & \multicolumn{4}{|c|}{$\begin{array}{l}\text { Above } \\
\text { Average Performance }\end{array}$} \\
\hline & & 1 & 2 & 3 & 4 & 5 & 6 & 7 \\
\hline MP_01 & $\begin{array}{l}\text { Determining goals, policies, and lines of action (for example, work } \\
\text { scheduling, budgeting). }\end{array}$ & & & & & & & \\
\hline MP_02 & $\begin{array}{l}\text { Collection and preparation of information, usually in the form of } \\
\text { records, reports, and accounts (for example, measuring production, } \\
\text { record keeping, job analysis). }\end{array}$ & & & & & & & \\
\hline MP_03 & $\begin{array}{l}\text { Exchanging information with people in your organization who are not } \\
\text { your subordinates, in order to relate and adjust programs (for example, } \\
\text { expeditions, liaisons with other managers, organizing meetings). }\end{array}$ & & & & & & & \\
\hline MP_04 & $\begin{array}{l}\text { Evaluating proposals or reported/observed performance (for example, } \\
\text { employee evaluations, judging output records, product inspection). }\end{array}$ & & & & & & & \\
\hline MP_05 & Guiding and leading the development of your subordinates. & & & & & & & \\
\hline MP_06 & $\begin{array}{l}\text { Maintaining the workforce of your unit (for example, employee } \\
\text { selection and promotion). }\end{array}$ & & & & & & & \\
\hline MP_07 & $\begin{array}{l}\text { Acquiring, disposing of, or contracting goods and services (for } \\
\text { example, tax negotiations, contracting suppliers, collective bargaining, } \\
\text { advertising). }\end{array}$ & & & & & & & \\
\hline MP_08 & $\begin{array}{l}\text { Leveraging the general interests of your organization through lectures, } \\
\text { consultations, or contact with others outside the organization. }\end{array}$ & & & & & & & \\
\hline MP_09 & How do you evaluate your overall performance? & & & & & & & \\
\hline
\end{tabular}




\section{Supporting Agencies:}

Coordination for the Improvement of Higher Education Personnel (CAPES) and the National Council for Scientific and Technological Development (CNPq). Article related to the Project "Research on managerial performance of managers with budgetary responsibility" (Process: 472195 / 2014-0).

\section{About the Authors:}

1. Micheli Aparecida Lunardi, Master in Accounting, Universidade Regional de Blumenau - Brasil.

E-mail: micheli.lunardi@yahoo.com.br

\section{ORCIID}

(D) 0000-0003-0622-928X

2.Vinícius Costa da Silva Zonatto, Doctor in Accounting, Universidade Regional de Blumenau, Universidade Federal de Santa Maria - Brasil. E-mail: viniciuszonatto@gmail.com

\section{ORCIID}

(iD) 0000-0003-0823-6774

3. Juliana Constâncio Nascimento, Master in Accounting, Universidade Regional de Blumenau - Brasil.

E-mail: jcbrida@hotmail.com

ORCIID

(D) 0000-0002-8661-127X

Has any preliminary version of this article been presented / published in annals of scientific congresses or is it derived from a thesis or dissertation? Yes.

Title of the article: Effects of Job Involvement, Attitudes, and Information Sharing on Controllers' Management Performance in the Budgetary Context.

Authors: Micheli Aparecida Lunardi. Vinícius Costa da Silva Zonatto, and Juliana Constâncio Nascimento. Event name: III Congress of Accounting of UFRGS.

Place: Porto Alegre.

Date: $08 / 30 / 2018$ to $08 / 31 / 2018$.

\section{Contribution of each author}

\begin{tabular}{|c|c|c|c|}
\hline Contribution & Micheli Lunardi & $\begin{array}{l}\text { Vinícius } \\
\text { Zonatto }\end{array}$ & $\begin{array}{c}\text { Juliana } \\
\text { Nascimento }\end{array}$ \\
\hline 1. Definition of research problem & $\sqrt{ }$ & $\sqrt{ }$ & \\
\hline 2. Development of hypotheses or research questions (empirical studies) & $\sqrt{ }$ & $\sqrt{ }$ & \\
\hline 3. Development of theoretical propositions (theoretical work) & $\sqrt{ }$ & $\sqrt{ }$ & \\
\hline 4. Theoretical foundation/ Literature review & $\sqrt{ }$ & $\sqrt{ }$ & \\
\hline 5. Definition of methodological procedures & $\sqrt{ }$ & $\sqrt{ }$ & \\
\hline 6. Data collection & $\sqrt{ }$ & $\sqrt{ }$ & $\sqrt{ }$ \\
\hline 7. Statistical analysis & $\sqrt{ }$ & $\sqrt{ }$ & $\sqrt{ }$ \\
\hline 8. Analysis and interpretation of data & $\sqrt{ }$ & $\sqrt{ }$ & \\
\hline 9. Critical revision of the manuscript & $\sqrt{ }$ & $\sqrt{ }$ & $\sqrt{ }$ \\
\hline 10. Manuscript writing & $\sqrt{ }$ & $\sqrt{ }$ & \\
\hline 11. Other (please specify which) & & & \\
\hline
\end{tabular}

